\title{
Your next boss is American: Attitudes of South African managers towards prospective US-South African joint ventures
}

\author{
W. A. Akande* \\ University of KwaZulu-Natal, \\ Graduate School of Business \\ Durban 4000, Republic of South Africa \\ akandea@ukzn.ac.za; akand@uymail.com \\ M. Banai \\ Baruch College, The City University of New York, \\ USA \\ Received February 2009
}

\begin{abstract}
This study explores South African managers' expectations of prospective South African - United States international joint ventures. One hundred and three middle-level South African managers responded to a theory-based original survey questionnaire that included questions about various aspects of prospective US-South African joint ventures. US companies invest in South Africa to gain access to its market and South African companies get into joint ventures with US companies to tap into their financial resources. Tarrifs imposed by the US government and the South African government's administrative barriers seem to be the most crucial problems for the prospective joint ventures. Implications for international managers are offered.
\end{abstract}

*To whom all correspondence should be addressed.

\section{Introduction}

“One doesn’t realise how different cultures can be until you visit another differing cultural society or nation”

(Beatrice Agbeke, 2007).

"The distinctive characteristic of a joint venture, which is shared ownership, is also its key problem"

(Gerlinger \& Hebert, 1989).

In the last twenty years, several authors have recognized the relevance of, and the need to address the issue of formation and dissolution of international joint venture (e.g., Akande, 1992a; Berdrow \& Lane, 2003; Chalos \& O’Connor, 2004; Desai, Foley \& Hines, 2004; Tong, Reuer \& Peng, 2008). As the global economy has become a reality, much of the extant organizational and business literature which are based on research on successful performance of an international joint ventures have failed to take into account that the process of selecting a partner has become 'an increasingly complex decision process' (Hajidimitrou \& Georgiou, 2002; Madhok, 2006; Tong, Reuer \& Peng, 2008) .

This study explores South African managers' expectations of prospective joint ventures with US companies. This topic is of great importance since the cumulative foreign direct investment in South Africa since 1994 to date is estimated at $\$ 18.4$ billion (www.businessmap.co.za.), and the lion share of this foreign direct investment was in the form of joint ventures or buying into existing enterprises. There was very little foreign direct investment in new enterprises, a trend that hit hardest in the struggling black business sector in South Africa, giving the history of the nation. The economic sectors of activities in which joint ventures are most common in South Africa are research and development, national resource exploration and exploitation, engineering and construction, production/manufacturing, buying and selling and services (www.wwb.co.za).

United States direct investment in South Africa rose from about US\$871 million in 1992 to more than US\$1.34 billion in 1995 (http://lcweb2.loc.gov/frd/cs/zatoc.html). Foreign direct investment by US companies in South Africa stood at R19.6 billion ( $\$ 2.76$ billion) at the end of 2000 . About 800 American companies, including subsidiaries, agents, distributors and franchisees employ over 100,000 people in South Africa (http://pretoria.usembassy.gov). United States direct investment in South Africa reached \$3.427B in 2002 (www.bea.gov/bea/ARTICLES/2003/09September/0903usd ia). (The search for information on the current business transaction was futile.)

US corporations returned to South Africa after about ten years of boycotting the country for its human rights violations. For instance, in 1994, prominent African Americans such as Danny Glover, Shaquille O'Neal, and Johnnie L. Cochran invested \$15M in a PepsiCo Bottling joint venture (USA Today, October 4, 1994). In 1995, 
Electronic Data Systems Corp., a daughter company of General Motors, formed a joint venture with Dimension Data Holdings Ltd. of South Africa (Los Angeles Times, March 9, 1995). In the same year, Donaldson, Lufkin \& Jenrette Inc., a unit of the Equitable Companies, formed an investment banking joint venture in South Africa with an affiliate of New Africa Investments Ltd (New York Times, October 5, 1995). Additionally, United Healthcare Corporation established a joint venture in the field of healthcare with two of South Africa's leading corporations: Anglo American Corporation and Southern Life (PR Newswire, September 13, 1995). The giant Heinz established a pet food joint venture with Tiger Oats Limited of Johannesburg in 1997. The company is known as Pets products (PTY) Limited with its headquarters in Cape Town (Universal News Services, July 22, 1997).

In addition to its commercial importance Hofmeyr, Templer, \& Beaty (1994) advised on the advantages of conducting research in South Africa. They suggested that the rapid changes that take place in South Africa pose challenges for the researcher but also offer unparallel opportunities in examining the interplay between developed and developing world perspectives on management. They recommend researchers to study culture, people, and the region.

Studies of South African organizations have focused on small businesses (Radder, 2000; Tait \& Tait, 2000; Van Eeden, Viviers \& Venter, 2003), retail (Abratt \& Da Silva, 2002) and entrepreneurship (Kropp \& Lindsay, 2001; Mangaliso \& Nkomo, 2001a; 2001b). Some studies have investigated employees' attitudes such as organizational commitment (Arnolds \& Boshoff, 2002) or employees' needs (Arnolds \& Boshoff, 2003). Others looked into the effect of organizational structure on internal communication (Akande \& Odewale, 1994; Holtzhausen, 2002), ethnic diversity and managerial effectiveness (Boersma, Buckley \& Ghauri, 2003; Ghosh, 2001), cross-cultural studies where South Africa was one of the countries studied (Jackson, Hill, Tamangani \& Chipandambira, 2000), Managerial Assessment centres (Engelbrecht \& Fischer, 1995), ethics (Badenhorst, 1994), and the research environment (Hofmeyr et al., 1994). However, no study could be found that investigates international joint ventures in South Africa. This is despite the opportunities for research identified by Hofmeyr et al., (1994) and the importance of this topic for South African as well as for foreign companies. In the following section we (the authors) first define joint ventures and describe potential strategies to study them. Later, the present authors explore management patterns in South Africa and elicit the attitudes of South African managers toward prospective South African - US joint ventures on several major issues.

\section{The theory and practice of International Joint Ventures (IJVs)}

An international joint venture is an association of two or more natural or legal persons from different countries combining property and expertise to carry out a single business enterprise and having a joint proprietary interest, a joint right of control, and a sharing of profits and losses (Banai, Chanai \& Teng, 1999). IJVs have been an important research topic for years (Adner \& Levinthal, 2004; Beamish, 1988; Boersma et al., 2003; Chi, 2000; Harrigan, 1985; Killing, 1983; Madhok, 2006; Zaheer, Schomaker \& Genc, 2003), as they are difficult to manage and have a high failure rate (Berdrow \& Lane, 2003; Desai, Foley \& Hines, 2004; Gomes-Casseres, 1987; Hajidimitriou \& Georgiou, 2002; Kogut, 1988a; Shenkar \& Yan, 2002; Tong, Reuer \& Peng, 2008). There are five strategies that have been applied to the study of the effectiveness of IJVs. The first strategy analyzes the characteristics of the parent companies as the determinants of the IJVs' performance (Hennart, 1988; Hennart \& Zeng, 2002; Shenkar \& Zeira, 1987). The second strategy relates IJV effectiveness to a number of aspects of IJVs, such as their technological, structural, and behavioral dimensions (Dollios \& Henisz, 2000; Dyer, Kale \& Singh, 2004; Folta \& Miller, 2002; Lane \& Beamish, 1990; Reich \& Mankin, 1986). In this case, the IJVs rather than the parent companies are singled out as research subjects. These two strategies are widely used to analyze IJVs after they have been forged. The third strategy uses executives' expectations of IJVs as the background for improving the effectiveness of prospective IJVs (Baird, Lyle \& Wharton, 1990; Banai, Chanin \& Teng, 1999; Guillen, 2002; Ireland, Hitt \& Vaidyanath, 2002). This strategy is applicable during the initial steps considering the establishment of IJVs, the actual act of forging them, and the final process of managing them, and it has been applied in this study. The fourth strategy is the development of trust in IJVs over time. Competence-based trust should develop before the parties come together to negotiate (Boersma et al., 2003; Madhok, 2006). Complementary to these four approaches is the fifth strategy that views JVs as growth options. The real options theory can help managers seeking growth options in IJVs to identify conditions under which such investments are possible, through a focused view on three IJV attributes of ownership structure, product-market focus and geographical location (Tong, Reuer \& Peng, 2008)

In the next section we explore South African managers' expectations of the motives for the partners in a potential US - South African joint venture, problems that may immerge in these joint ventures, strategies that should be applied, equity and managerial control, and desired US managers' behavior and human resource practices.

\section{South African managers' expectations}

\section{Motives for entering into IJVs}

The motives for entering into IJVs are important to both partners. In a comprehensive review on joint venture motives, Lin, Yu and Seetoo (1997) conclude that there are three types of reasons to form IJVs: efficiency (to reduce costs, utilize resources efficiently, reduce risks, or overcome governmental restrictions), competition (to reduce competition or enhance market power), and learning (to gain a partner's know-how or resources).

In a rare research of IJVs in African contexts, Boateng and Glaister (2002) found that congruity of motives and goals, among other factors, are significant determinants of IJV performance. Park and Ungson (1997) found that cultural differences between the partners are not the major indicators 
for joint venture's dissolution. Rather market overlap and technology transfer between partners, both of which increase inter-partner competition, lead to unsuccessful venture experience (Pantzalis, 2002).

Based on these findings it was expected that South African and US firms' motives for entering IJVs would basically complement each other. As a strategy to pursue FDI opportunity, IJVs has advantages over other strategies precisely because it allows the parent firms to pool their resources. Thus when the parent firms contribute complementary resources synergy occurs. As the justification for having IJVs is to access complementary resources possessed by the partners, the firms should find themselves having different but complementary motives. In this sense, since South African - US joint ventures are generally viewed as a good match, it was expected that the South African managers justification of the IJVs would follow this logic.

The main motive for foreign companies from less developed countries in establishing IJVs with companies from developed countries is getting access to financial and technological resources. Hence, we propose the following hypotheses:

H1 South African managers expect potential US parent company to provide them with financial and technological resources.

The main motive for foreign companies from developed countries in establishing IJVs in less developed countries is getting access to the local market.

\section{H2: South African managers expect a potential US parent company to look for access to the local market.}

\section{Potential problems and costs of shared ownership}

The second bottleneck relates to potential problems faced by South African and US firms in SA-US joint ventures. The key concern of partners is to ensure the availability of resources that they do not already possess. Thus it was expected that those factors being cited by South African managers should be closely related to what the firm hoped to get from its partner. For instance, in many cases the US firms provided the technological know how while the South African firms contributed their knowledge of the local political, economic and cultural system to the IJV. Hence the major problems for South African firms were expected to focus on technology transfer or a lack of it. Additionally, since US partners are often expected to provide managerial expertise, heavy presence of US personnel seems inevitable. Nevertheless, what one US expatriate earns could be ten times more than that of a South African manager, and the difference in their performance often does not justify such disparity. Great disparity in compensation not only becomes a financial burden for the joint venture, but also triggers a sense of inequity among the employees, which is likely to undermine work motivation. The potential problems for US firms were expected to be related to their inability to gain access to local markets because of political or other circumstances. Additionally, dramatic difference in economic development of the two countries witnesses consequent different work habits in each country. US managers in South Africa are expected to view South African employees work behavior problematic. Based on the above, we propose the following hypotheses:

H3: South African managers expect to face problems in potential US JV partners' transfer of financial resources and technology, and in the cost of US personnel.

H4: South African managers expect US managers to face problems in gaining access to local resources such as workforce and markets, and in managing the local workforce.

\section{Parent company's strategy}

Drawing from some successful IJV experiences in China, a focused strategy could be the key to the success of a joint venture established in those countries that are willing to learn advanced management and operation experience of well-developed industries such as the American industries. It was suggested that a highly rigid, restrained, hands-on, and internally oriented approach rather than flexible, consultative management would be more effective in securing the IJVs' position and generating results in such countries. Therefore a focused strategy is usually recommended for IJVs in transforming economies (Chalos \& O’Connor, 2004; Newman, 1992).

The five facets of this focused IJV strategy are: (a) prescribed operations -full instructions on how to perform each job; (b) narrow product line - focusing on only a few related products; (c) sustained commitment of partners to the initial, relatively simple focus of the IJV; (d) motivated employees who accept the distinctive character of the IJV; (e) strict performance standards for local suppliers. These rules enable the IJVs to focus on the operating side of management, and thus maximize current performance (Lin et al., 1997).

The presumption of focused IJV strategy is that the priority for the IJVs in such countries is to achieve desirable performance in the short run. It can be argued that if the foreign partner cannot see immediate gains in a highly volatile market, it is likely that it will pull out quickly. Indeed, many large corporations see IJVs as a transitional mode on their way to the establishment of wholly owned subsidiaries (Beamish \& Inkpen, 1995; Inkpen \& Beamish, 1997; Kogut, 1989; Prahalad \& Lieberthal, 2003). Such practice triggers doubt about sustainable cooperation, which certainly casts a shadow on current performance of South African - US joint ventures (Tang et al., 2006). While conflict of that nature is possible in US - South African joint ventures it would be impossible to identify it using the current research framework. Nevertheless, South African managers may expect a US partner to adopt a focused strategy. Hence, the following hypothesis is offered:

\footnotetext{
H5: South African managers expect US JV's partners to adopt a focused strategy.
} 


\section{Equity control}

The need for control is directly reflected in the pattern of equity ownership (Desai et al., 2004; Blodgett, 1991; Geringer \& Hebert, 1989). A majority equity ownership implies more control over the joint venture, simply because the firm with the majority equity represents the largest shareholder. The majority owner is thus granted veto power over major decisions of the IJV. The second argument for majority equity ownership is to gain more profit from the IJV since equity share serves as the basis for profit distribution

Gaining majority control, mainly through majority equity, does not always ensure better performance. The arguments for dominant control hold that one dominant parent takes charge of the joint venture and makes it easier to manage (Killing, 1983). The counter-arguments posit that dominant control of one parent hampers the learning ability of the other parent and therefore limits the potential of the joint venture (Beamish, 1984). Empirical studies have also provided evidence that dominant control by foreign companies setting up joint ventures in developing countries is related to both successful (Killing, 1982; Hebert, 1996; Tong \& Reuer, 2006) and unsatisfactory performance (Beamish, 1988; Awadzi, 1987; Kogut, 1988b; Rosenkopf \& Almeida, 2003). In the study of 57 IJVs in West Africa, Boateng and Glaister (2002) reported that control level is negatively related to IJV success, encompassing multiple financial and non-financial performance measures. Specifically, when host (West African) partner makes the overall decisions or the host and foreign partners equally share controls, the IJV is assessed as less successful by its managers. At the same time a recent study on 67 manufacturing IJVs in China with various foreign partners (Child \& Yan, 2003) found that sharing control with local partners predicts higher IJV performance.

Thus, it can be expected that US firms that can afford it financially would strive to take more shares of equity in IJVs. We expect South African managers to wish for a majority equity ownership as well. Yet, since the main objective of the South African managers in getting into joint ventures in the first place is expected to be gaining access to US financial resources, it is clear that the South African managers will accept equal ownership or even a majority holding by the US partners. Based on the literature reviewed earlier, and our framework, we derive the following hypothesis:

\section{H6: South African managers expect equal ownership in the IJV.}

\section{Managerial control}

A way to assume better control of the IJVs is by assigning parent country managers to key positions in the IJVs (Geringer \& Herbert, 1989; Mjoen \& Tallman, 1997). The position of a general manager of an IJV is especially critical. Besides the post of the general manager, other managerial positions are of importance as well. In fact, one researcher suggested that the Western partners should negotiate to appoint $50 \%$ of the venture's directors, as well as managers responsible for quality control, technology use and production (Hough, 1990; Wright, Filatotchev, Hoskisson, \& Peng, 2005). To have its own people in key managerial positions will help the US parent firm ensure control over the joint venture (Yan \& Gray, 1994; Yan, 2003). At the same time South African managers would intuitively prefer the assignment of local nationals to management positions to ensure more managerial control. The following hypothesis is delineated:

\section{H7: South African managers expect to gain managerial control in the IJV}

\section{Management philosophy}

Hofstede $(1980 ; 1997)$ has revealed that persons living a particular nation tend to share similar values and they come to their workplaces with these values. A person's culture is a composite of such factors as the person's ancestral culture, level of accumulation, racial/ethnic identity development and unique personal experiences. However, culture should be understood to be a multi-faceted, complex structure rather a simple categorical model (Hennart \& Zeng, 2002; Triandis, 1995).

The individualism/collectivism dimension describes the degree to which a society emphasizes either individual or group welfare. Individualist cultures promote 'self realization' for their members - that is individual's greatest responsibility is to oneself and one's immediate family; the translation of each person's unique set of talents and potential into actuality is the highest purpose to which one can devote one's life. In contrast, the collectivist culture emphasizes relationships even if they are disadvantageous. The assumption that people are bound together in tight groups of interdependent individuals is fundamental to collectivist societies (Akande 1991a; Triandis \& Gelfand, 1998).

Thus, a company's values are largely a reflection of its national culture (Akande, 1991b; 1992a). To this end, we should expect IJVs based in different countries to have variety of values. Hofstede (1997) further suggests that various dimensions of culture, such as power distance and uncertainty avoidance, greatly influence personal management philosophy. High power distance societies are characterized by hierarchical structures in which obedience, conformity, strict control, and autocratic decision-making are highly valued. In contrast, in low power distance societies the managerial behavior is likely to be participate, egalitarian, and democratic. Uncertainty avoidance identifies the extent to which a society feels threatened by uncertain and ambiguous situations. Managers from societies high on uncertainty avoidance tend to prefer structured organization, established rules, low labor turnover, and are more task-oriented.

More recently a group of scientists (House et al., 2004) have published a research report that factored people's values into nine cultural dimensions. Power Distance is the degree to which members of a collective expect power to be distributed equally. Uncertainty Avoidance is the extent to which a society, organization, or group relies on social 
norms, rules and procedures to alleviate unpredictability of future events. Humane Orientation is the degree to which a collective encourages and rewards individuals for being fair, altruistic, generous, caring and kind to others. Institutional Collectivism is the degree to which individuals are integrated into groups within the society. In-Group Collectivism is the degree to which individuals have strong ties to their small immediate groups. Assertiveness is the degree to which individuals are assertive, dominant and demanding in their relationships with others. Gender Egalitarianism is the degree to which a collective minimizes gender inequality. Future Orientation is the degree to which a collective encourages and rewards future oriented behaviors such as delaying gratification, planning and investing in the future. Performance Orientation is the degree to which a collective encourages and rewards group members for performance improvement and excellence.

South African managers scored high on Institutional Collectivism, averagely on In-Group Collectivism, high on Humane Orientation, above average on Uncertainty Avoidance, High for white managers and low for black managers on Power Distance, High on Assertiveness, High on Performance orientation High on Future Orientation, and high on Gender Egalitarianism in the GLOBE study (House et al., 2004).

As South Africa presents a relatively low power distance society (Hofstede, 1980, 1997; Tang et al., 2006), it was expected that SA managers would support flexible and nonhierarchical control systems. Similarly SA managers scored comparatively low on uncertainty avoidance (Hofstede, 1980) and therefore were expected to depict risk-taking characteristics. Moreover, in many aspects of their value system South African managers tend to be group, egalitarian and humane oriented (Akande, 1992b; Tang et al., 2006).

Yet research findings suggest that South African common management style is characterized by centralized decisionmaking where systematic delegation is rare. Teamwork is uncommon and information is not available. While education is a desired qualification for getting a job, promotions are mostly based on seniority. Family relations, kinship and tribes are part of the informal network that is used to dictate individuals' appointments and promotions. Planning is very short term. Managers are mostly engaged in problems' shooting. This culture puts high demands on the top manager to be very knowledgeable and to be able to sort out problems of any kind at all times (Akande, 1994; Arnolds \& Boshoff, 2002; Arnolds \& Boshoff, 2003; Mangaliso, 2001; Wallroth, 1998).

Consequently, South African managers are expected to perceive the ideal US manager in IJVs as task oriented rather than paternalistic and as someone who adopts supportive yet results oriented human resource practices that are directed toward the group rather than toward the individual. Based on the preceeding discussions, the following hypothesis is plausible:

H8: South African managers expect the IJV's foreign manager (a) to be people and group oriented, (b) to adopt a managerial policy that is group oriented, and (c) to apply egalitarian and group oriented human resource practices

\section{Methodology}

\section{Data collection}

The participants in the study were 103 out of 180 (57\%) managers from several industries, such as financial services, telecommunication, and manufacturing, attending a South African management centre for short courses between April and September 2006. The director of the management center was informed about the nature of the research. As the study was undertaken during class periods, the participants were recruited on a voluntary basis and seemed willing to comply fully with study requirement. The respondents were notified that the survey questionnaire was confidential and anonymous. To help preserve response confidentiality respondents were given an envelope with their surveys. Thus, completed surveys were enclosed in a large envelope before being given back to the investigator in the class. The survey was administered in the English language, as the managers' command of the language was highly proficient.

\section{Respondents}

Female respondents made up $60.20 \%$ of the total 103 respondents. The average respondent was 45.6 years old with 18.5 years of education.

\section{Instruments}

A questionnaire containing six relevant issues was designed in order to understand the meaning of IJV to South African managers and those managers' inclination to run South African-US joint ventures. Tables 1-7 illustrate the content of this questionnaire. Based on extensive literature review and personal interviews with managers the authors have developed most of the measures, including those of motives and potential problems.

For example, the various motives and problems associated with South Africa-US joint ventures were developed by consulting with existing studies on the subject. The five questions about the focused IJV strategy (Table 3) were constructed based on Newman's (1992) description, which lists five important aspects of a focused JV strategy. For these measures, an ordinal scale was used so that the respondents were asked to rank each choice in a pool of items. For instance, in a measure consisting of 10 items (e.g. cost of US labour as a motive for entering South African-US joint venture), assigning a value of ' 1 ' to the item indicated that the item had first priority, while assigning a value of ' 10 ' meant that the item had the least priority among the ten items. Equity control was measured by selecting one of three options: US parent company possesses majority equity, South African parent company possesses majority equity, or the two partners share equity. Managerial control was measured by asking the respondent to select one of the following policies: South African managers hold all managerial position, South African managers hold majority of managerial position and US managers hold the rest, South African and US managers equally hold managerial positions in the JV, US managers hold most managerial jobs and South African managers hold the rest, and US managers hold all managerial positions (Table 4). 
We adopted two existing measures of personnel management philosophy and ideal IJV manager from a previous study where a satisfactory validity of the measures was achieved (Baird \& Lyle, 1990). A five-point scale was used for these two measures. The respondents selected a value between 1 and 5, when 1 indicates 'to a very small extent' and 5 represents 'to a very large extent.' For example, selecting ' 1 ' as an answer to the statement 'managers should expect the workers to follow instructions' indicates that the respondent assesses it as having very low importance.

\section{Statistical analyses}

In this study, since several variables used ordinal scales (see Tables 1 to 3), they represent related samples in meancomparison tests (i.e. the rank of one variable necessarily affects the ranks of other variables). Therefore, the Friedman test, a nonparametric test comparing the distribution of several related variables, was used. Friedman's two-way ANOVA tests examine the null hypotheses that the scores in each topic come from the same population (i.e. their ranks are not significantly different).

Friedman's tests results that are significant $(\mathrm{P}<0,05)$ enable us to reject the null hypotheses and to conclude that the differences in the ranking of the variables are significant.

Meanwhile, the scales in the variables in Tables 4 to 7 were interval. Regular Chi-square tests were used to test equal distribution of each of the 27 variables. The null hypotheses were that for each of these variables respondents randomly choose from 1 to 5 (or 1 to 3 ).

Chi-Test results that are significant $(\mathrm{P}<.05)$ allow us to reject the null hypotheses and to conclude that the variables are not equally or randomly distributed and that the differences in their means are thus likely to be attributed to some underlying differences in the population.

\section{Results}

\section{Motives for entering South African-US joint ventures}

By far the most salient motive for South African firms' entering South African-US joint ventures is to obtain US partner's financial resources (see Table 1).

Among 103 respondents, only 11 did not rank this motive as the first choice. Obviously the overall fiscal difficulties (state revenues and expenses) facing South Africa have a direct impact on the cooperation motive of South African enterprises with their US partners. Similarly, South African managers believe that US partners have a single top-ranking objective: gaining access to the local market. Such mutual dependence suggests a good match between the US and South African partners, and will mostly contribute to satisfactory performance. Hypotheses 1 and 2 are corroborated.

It has to be noticed that technology transfer in both directions between the partners is ranked $4^{\text {th }}$ by South African managers regarding their own expectations and their prediction of the US managers' expectations. This should constitute a warning for both partners since inter-partner competition is likely to pose tensions in the joint venture (Park \& Ungson, 1997).

\section{Potential problems}

\section{Problems for South African partners}

We predicted that the expected problems, or concerns, of both US and South African companies were likely to focus on the resources that would be made available to each partner through joint venture. This general pattern seems to be reflected in South African managers' expectations (see Table 2).

Table 1: Motives for entering South African-US joint ventures $(\mathrm{N}=103)$

\begin{tabular}{c|l|c}
\hline \multicolumn{2}{|c}{ Motives of South African firms } \\
\hline & \multicolumn{1}{|c}{$\begin{array}{c}\text { Mean } \\
\text { rank* }\end{array}$} \\
\hline 1 & US partners' financial resources & 1,6 \\
\hline 2 & Cost of US labor & 4,8 \\
\hline 3 & Gaining access to foreign markets & 4,9 \\
\hline 4 & Technology transfer by the US partners & 5,1 \\
\hline 5 & Preferential access to US market & 5,6 \\
\hline 6 & US partners' economies of scales & 5,7 \\
\hline 7 & Overcoming US non-tariff barriers & 5,8 \\
\hline 8 & Managerial skills of US managers & 5,8 \\
\hline 9 & Handling high US market entry cost & 5,9 \\
\hline 10 & Avoidance of US tariff barriers & 9,8 \\
\hline Friedman's ANOVA & 389,05 \\
Chi-square significance & 0,00 \\
\hline
\end{tabular}

Motives of US firms (N=103)

\begin{tabular}{c|l|c}
\hline 1 & Preferential access to South African market & 1,7 \\
\hline 2 & Gaining access to foreign market & 5,1 \\
\hline 3 & Cost of South African labor & 5,1 \\
\hline 4 & Technology transfer by the South African & 5,3 \\
\hline 5 & South African partners’ economies of scale & 5,3 \\
\hline 6 & Handling South African market entry cost & 5,3 \\
\hline 7 & South African partners’ financial resources & 5,5 \\
\hline 8 & Managerial skills of South African managers & 5,5 \\
\hline 9 & Overcoming South African non-tariff barriers & 6,3 \\
\hline 10 & Avoidance of South African tariff barriers & 9,7 \\
\hline Friedman ANOVA & 377,77 \\
Chi square & 0,00 \\
\hline \multicolumn{2}{l}{ Significance }
\end{tabular}

1=most important; $10=$ least important 
Table 2: Potential problems in South African-US joint ventures $(\mathbf{N}=103)$

\begin{tabular}{|c|c|c|}
\hline \multicolumn{3}{|c|}{ Problems for South African firms } \\
\hline & & $\begin{array}{l}\text { Mean } \\
\text { rank }\end{array}$ \\
\hline 1 & US tariff barriers are high & 1,3 \\
\hline 2 & US labor cost is too high & 2,1 \\
\hline 3 & US partner does not transfer technology & 5,5 \\
\hline 4 & US non-tariff barriers are high & 5,6 \\
\hline 5 & US market entry cost is high & 5,8 \\
\hline 6 & $\begin{array}{l}\text { US partner would provide limited access to US } \\
\text { market }\end{array}$ & 6,2 \\
\hline 7 & $\begin{array}{l}\text { US partner would provide limited access to } \\
\text { foreign markets }\end{array}$ & 6,2 \\
\hline 8 & US partner lacks financial resources & 6,2 \\
\hline 9 & US partner lacks managerial skills & 6,5 \\
\hline 10 & US partner is of small scale & 9,0 \\
\hline $\begin{array}{l}\text { Frie } \\
\text { Chi- } \\
\text { Sign } \\
\end{array}$ & $\begin{array}{l}\text { an's ANOVA } \\
\text { dare significance } \\
\text { cance }\end{array}$ & $\begin{array}{r}483,3 \\
0,00 \\
\end{array}$ \\
\hline \multicolumn{3}{|c|}{ Problems for US firms } \\
\hline 1 & Government regulations are volatile & 1,1 \\
\hline 2 & $\begin{array}{l}\text { Prevailing work habits condone poor quality } \\
\text { and high cost }\end{array}$ & 2,1 \\
\hline 3 & Foreign exchange is scarce & 5,6 \\
\hline 4 & $\begin{array}{l}\text { Local suppliers of goods and services are not } \\
\text { well-established }\end{array}$ & 5,8 \\
\hline 5 & $\begin{array}{l}\text { Centralized planning has snuffed out local } \\
\text { initiative }\end{array}$ & 6,0 \\
\hline 6 & $\begin{array}{l}\text { Interference of illegal agents in the company's } \\
\text { business }\end{array}$ & 6,0 \\
\hline 7 & Management controls are ineffective & 6,1 \\
\hline 8 & The ability to export is uncertain & 6,2 \\
\hline 9 & Work motivation for workers and mans & 6,2 \\
\hline 10 & Inefficient contract and business legal system & 10,0 \\
\hline $\begin{array}{l}\text { Frie } \\
\text { Chi } \\
\text { Sign } \\
\end{array}$ & $\begin{array}{l}\text { an ANOVA } \\
\text { Iare } \\
\text { cance } \\
\end{array}$ & $\begin{array}{r}589,42 \\
0,00 \\
\end{array}$ \\
\hline
\end{tabular}

South African managers' single most salient problem for South African firms is the high US tariff barriers. This demonstrates the incentive of South African partners to access US market resources. The second potential problem for South African partners is the high cost of US personnel in the venture. Thus, Hypothesis 3 is corroborated.

\section{Problems for US partners}

Most South African managers expect that the single most serious problem for US companies involved in South African-US joint ventures is the volatility of government regulations. Indeed, the risk level of IJVs in South Africa is greatly highlighted by the South African government's tendency to alter regulations at its discretion, which often represents an ad hoc approach to problems.

Our findings reveal that prevailing work habits condone poor quality, uncertain delivery, and high costs are viewed as the second major problem for US firms in South Africa. Thus hypothesis 4 is corroborated.

\section{Parent company's strategy}

Among the five policies - 'prescribed operations' and 'narrow product line' - the two rules that best capture the spirit of focused strategy, did get much attention (see Table 3).

Table 3: Focused strategy for South African-US joint ventures $(\mathrm{N}=103)$

\begin{tabular}{c|l|c}
\hline & \multicolumn{1}{|c}{$\begin{array}{l}\text { Mean } \\
\text { rank }\end{array}$} \\
\hline 1 & $\begin{array}{l}\text { JV should concentrate on producing only a } \\
\text { few related products }\end{array}$ & 2,4 \\
\hline 2 & $\begin{array}{l}\text { Employees should receive full instructions on } \\
\text { how each job is to be performed }\end{array}$ & 3,0 \\
\hline 3 & $\begin{array}{l}\text { JV should insist that suppliers of materials, } \\
\text { parts and service accept the JV's standard }\end{array}$ & 3,4 \\
\hline 4 & $\begin{array}{l}\text { JV should sustain a continuing strong and } \\
\text { undeviating support by both founding partners } \\
\text { to the initial focus of the JV }\end{array}$ & 4,3 \\
\hline 5 & $\begin{array}{l}\text { Employees should enthusiastically accept the } \\
\text { distinctive character and role of the JV }\end{array}$ & 4,3 \\
\hline \multicolumn{2}{l|}{$\begin{array}{l}\text { Friedman's ANOVA } \\
\text { Chi-square significance }\end{array}$} & 167,28 \\
Significance & 0,00 \\
\hline
\end{tabular}

It seems that South African managers are quite willing to see themselves preoccupied with operational details. They are relatively less eager to cooperate with US partner's exploration of long-term opportunities in the market. The results confirmed hypothesis 5.

\section{Equity and management control}

Our survey finds that $47,20 \%$ of South African managers reported that it was desirable to have both sides share equal equity control (see Table 4). 42,7\% of them preferred the US partner to sustain over $50 \%$ of equity ownership. The results conform to the main motive for South African firms to enter IJV, which is to get the financial resources from US partners. Hypothesis 6 is corroborated.

65\% of South African managers preferred to have a few US managers assigned to top positions in the joint ventures and fill the rest of the positions with South African managers. On the one hand, this is consistent with the recommendation for the US partner to have majority ownership that entails having top US management. On the other, it indicates South African partners' intention to balance the grip over the JV's control by having some managerial control that has the potential to compensate for the lack in financial control. Hypothesis 7 is not corroborated.

\section{Management philosophy}

Measures of personal management philosophy and managers' organizational attitudes and preferences are presented Table 5. 
Table 4: Equity and managerial control $(\mathrm{N}=89)$

\begin{tabular}{|c|c|c|c|}
\hline \multicolumn{4}{|c|}{ Equity ownership } \\
\hline & & \multicolumn{2}{|c|}{ Percentage (n) } \\
\hline 1 & Over $50 \%$ for the US company & $42,7 \%$ & (38) \\
\hline 2 & $\begin{array}{l}50 \% \text { for the US company and } 50 \% \text { for the } \\
\text { South African company }\end{array}$ & $47,2 \%$ & (42) \\
\hline 3 & Over 50\% for the South African company & $10,1 \%$ & (7) \\
\hline & $\begin{array}{l}\text { man's ANOVA } \\
\text { quare significance } \\
\text { ficance }\end{array}$ & $\begin{array}{r}167,28 \\
0,00\end{array}$ & \\
\hline \multicolumn{4}{|c|}{ Managerial composition } \\
\hline 1 & $\begin{array}{l}\text { Having US managers assigned to all top } \\
\text { positions in the joint ventures }\end{array}$ & $29 \%$ & $(26)$ \\
\hline 2 & $\begin{array}{l}\text { Having a few US managers assigned to } \\
\text { top positions in the JV and fill the rest } \\
\text { of the positions with South African } \\
\text { managers }\end{array}$ & $65 \%$ & $(58)$ \\
\hline 3 & $\begin{array}{l}\text { Having an equal mix of South African } \\
\text { and US managers in all }\end{array}$ & $1 \%$ & $(1)$ \\
\hline 4 & $\begin{array}{l}\text { Having a few South African managers } \\
\text { assigned to top positions in the JV and } \\
\text { fill the rest of the positions with US } \\
\text { managers }\end{array}$ & $5 \%$ & (4) \\
\hline & $\begin{array}{l}\text { man ANOVA } \\
\text { quare } \\
\text { ficance }\end{array}$ & $\begin{array}{r}39,51 \\
0,00\end{array}$ & \\
\hline
\end{tabular}

Table 5: Managerial philosophy

\begin{tabular}{|c|c|c|c|}
\hline & & Mean & $\begin{array}{l}\text { Chi } \\
\text { Square } \\
\text { Sig. }\end{array}$ \\
\hline 1 & $\begin{array}{l}\text { The work group is the most important } \\
\text { unit in an organization }\end{array}$ & 4,5 & 0,00 \\
\hline 2 & $\begin{array}{l}\text { Nothing is worse for a manager than } \\
\text { dealing with uncertainty }\end{array}$ & 4,4 & 0,00 \\
\hline 3 & $\begin{array}{l}\text { Groups make better decisions than } \\
\text { individuals }\end{array}$ & 4,3 & 0,00 \\
\hline 4 & $\begin{array}{l}\text { It is important to provide job security } \\
\text { so employees can work for the } \\
\text { company as long as they want }\end{array}$ & 4,0 & 0,00 \\
\hline 5 & $\begin{array}{l}\text { Managers should expect workers to } \\
\text { follow instructions }\end{array}$ & 4,0 & 0,17 \\
\hline 6 & $\begin{array}{l}\text { Managers should take a personal } \\
\text { interest in solving subordinates } \\
\text { problems that affect job performance }\end{array}$ & 3,7 & 0,00 \\
\hline 7 & $\begin{array}{l}\text { A manager's use of authority is often } \\
\text { necessary to assure that work is done } \\
\text { efficiently }\end{array}$ & 2,6 & 0,00 \\
\hline 8 & $\begin{array}{l}\text { A manager should keep important } \\
\text { work for himself and delegate } \\
\text { repetitive and mundane tasks to } \\
\text { subordinate }\end{array}$ & 2,1 & 0,00 \\
\hline 9 & $\begin{array}{l}\text { Managers should make most decisions } \\
\text { without consulting subordinates }\end{array}$ & 1,6 & 0,00 \\
\hline
\end{tabular}

$1=$ to a very small extent; $2=$ to a small extent; $3=$ to some extent;

$4=$ to a large extent; $5=$ to a very large extent

As a whole (see Table 5), South African managers endorse issues such as avoiding uncertainty (4.4), expecting workers to follow instructions (4.0), and providing job security to employees (4.0). Apparently, these characteristics point to less tolerance for uncertainty. Additionally, South African managers expect managers to consult with subordinates in the decision making process (1.6) and to delegate more important as well as repetitive and mundane tasks to subordinates (2.1). It is also found that South African managers expect teamwork. They believe that the work group is the most important unit in an organization (4.5) and better decisions are made by groups rather than by individual (4.3). Hypothesis 8a is corroborated.

\section{Ideal US managers of South African-US joint venture}

South African managers believe that an ideal US manager in IJVs should be people-oriented and humanistic (see Table 6).

\section{Table 6: Ideal US managers for South African-US joint ventures $(\mathrm{N}=103)$}

\begin{tabular}{|c|c|c|c|}
\hline & & Mean & $\begin{array}{l}\text { Chi } \\
\text { Square } \\
\text { Sig. }\end{array}$ \\
\hline 1 & $\begin{array}{llll}\begin{array}{l}\text { Maintain } \\
\text { relationship }\end{array} & \text { friendly } & \text { working } \\
\end{array}$ & 4,7 & 0,00 \\
\hline 2 & Provide rewards for individual efforts & 4,5 & 0,00 \\
\hline 3 & $\begin{array}{l}\begin{array}{l}\text { Explain the significance of group } \\
\text { efforts }\end{array} \\
\end{array}$ & 4,5 & 0,00 \\
\hline 4 & $\begin{array}{l}\text { Keep group attention focused on } \\
\text { important matters }\end{array}$ & 4,4 & 0,00 \\
\hline 5 & Provide feedback to employees & 4,3 & 0,00 \\
\hline 6 & $\begin{array}{l}\text { Demand highest work performance } \\
\text { standards }\end{array}$ & 4,3 & 0,00 \\
\hline 7 & $\begin{array}{l}\text { Detect style changes in technology for } \\
\text { the JV }\end{array}$ & 4,1 & 0,11 \\
\hline 8 & $\begin{array}{l}\text { Develop expertise in the technical } \\
\text { aspects of employees' jobs }\end{array}$ & 4,1 & 0,10 \\
\hline \multirow[t]{7}{*}{9} & $\begin{array}{l}\text { Encourage career development through } \\
\text { informal means }\end{array}$ & 4,0 & 0,00 \\
\hline & $\begin{array}{l}\text { Expose employees to other units in the } \\
\text { JV }\end{array}$ & 4,0 & 0,23 \\
\hline & $\begin{array}{l}\text { Keep employees posted on new } \\
\text { developments affecting them }\end{array}$ & 3,7 & 0,00 \\
\hline & $\begin{array}{l}\text { Explain expected standards of } \\
\text { performance }\end{array}$ & 3,5 & 0,00 \\
\hline & Consider feelings & 3,3 & 0,00 \\
\hline & $\begin{array}{l}\text { Believes that the JVs' objectives are } \\
\text { beyond making money }\end{array}$ & 3,3 & 0,00 \\
\hline & $\begin{array}{l}\text { Hold employees accountable for their } \\
\text { actions }\end{array}$ & 2,3 & 0,00 \\
\hline
\end{tabular}

$1=$ to a very small extent; $2=$ to a small extent; $3=$ to some extent; $4=$ to a large extent; $5=$ to a very large extent

The items deemed as most important are those closely related to employees' oriented leadership style (see Table 6). These items include maintaining a friendly working relationship (4.7), providing rewards for individual's efforts (4.5), and explaining the significance of group efforts (4.5). The least desirable to South African managers was the policy of holding employees accountable for their actions (2.3). Hypothesis 8b is corroborated.

\section{Desired human resource practices}

Table 7 depicts three issues that are in the center of South African managers desired human resources practices. 
Table 7: Desired human resource practices

\begin{tabular}{c|l|c}
\hline & \multicolumn{1}{|c}{$\begin{array}{l}\text { Mean } \\
\text { rank }\end{array}$} \\
\hline 1 & $\begin{array}{l}\text { Establish career path for employees and } \\
\text { managers }\end{array}$ & 1,1 \\
\hline 2 & Improve working conditions & 2,2 \\
\hline 3 & $\begin{array}{l}\text { Legislate against discrimination in the work } \\
\text { place }\end{array}$ & 3,2 \\
\hline 4 & Equip employees with job related skills & 6,0 \\
\hline 5 & $\begin{array}{l}\text { Improve methods of selection of employees to } \\
\text { the job }\end{array}$ & 6,0 \\
\hline 6 & $\begin{array}{l}\text { Equip managers with improved managerial } \\
\text { skills }\end{array}$ & 6,3 \\
\hline 7 & $\begin{array}{l}\text { Improve fringe benefits for employees and } \\
\text { managers }\end{array}$ & 6,4 \\
\hline 8 & $\begin{array}{l}\text { Improve compensation packages for } \\
\text { employees and managers }\end{array}$ & 6,5 \\
\hline 9 & $\begin{array}{l}\text { Match employees and managers rewards to } \\
\text { their performance }\end{array}$ & 6,7 \\
\hline 10 & $\begin{array}{l}\text { Improve employees' performance appraisal } \\
\text { methods }\end{array}$ & 9,7 \\
\hline Friedman’s ANOVA \\
Chi-square significance \\
Significance
\end{tabular}

First, they expect the JV's managers to establish career path for employees and managers (1.1) giving some certainty to their prospect, and guiding them in how to improve their positions in the IJV. Second, they expect working conditions to improve (2.2). Third, they expect discrimination in the workplace to be eliminated (3.2). These three basic elements in employment, usually taken for granted in advanced Western economies, are of most concern for the SA managers. Issues involved in modern human resource management methods, such as advanced methods of employees' selection and training, rational and justifiable compensation and benefits systems, and performance appraisal, did not get much attention. Hypothesis $8 \mathrm{c}$ is partially corroborated.

\section{Discussion}

South Africa has a great potential for US FDI in a form of IJVs. This study explores the expectations of South African managers of the desired policies and practices that US partners should employ in such joint ventures. The most important motive for South African firms' entering South African-US joint ventures is to obtain US partner's financial resources. US firms' most likely motivation to enter into JVs with SA partners is to gain preferential access to South African market and distribution sources. The two most salient problems for South African firms are the high US tariff barriers and the high cost of US personnel in the venture. The two most serious problems for US companies involved in South African-US joint ventures are the volatility of government regulations and the local prevailing work habits that condone poor quality, uncertain delivery, and high costs. To attract more US companies to invest in IJVs the South African government should stabilize the country legal system and work habits of South African workers are expected to undergo great improvement to adapt to US partners' requirement.
A highly rigid, restrained, hands-on, and internally oriented approach rather than flexible consultative management style would be more effective in securing the IJVs' position and generating results in South Africa.

About half of the South African managers reported that it was desirable to have both sides share equal equity control while another half preferred the US partner to sustain over one half of equity ownership. Very few managers sought South African partners to have a majority ownership. Apparently South African managers are aware to the fact that shared control, and majority control by the US partner, are believed to be associated with better organizational performance. This result supports conclusions reached by Killing (1982), Desai et al. (2004), Hebert (1996) and Madhok, (2006), and partially agrees with Boateng and Glaister's (2002) investigation in West Africa.

On the one hand, these findings may be good news for US firms that wish to take major control over South African-US joint ventures and gain access to more profit. On the other hand, to let South African partners have a smaller stake may not be a good choice since such arrangement may result in lower sense of commitment and less effort on the part of the South African firms.

The majority of the South African managers preferred to have a few US managers assigned to top positions in the joint ventures and argued that the rest of the positions should be reserved for South African managers. Assigning more local managers to joint ventures is becoming a trend in the management structure for joint ventures. Assigning local personnel to head JVs may help to cultivate South African managers, who in turn may improve management quality in this country.

South African managers expect US managers to employ decision-making style that avoids uncertainty, expect workers to follow instructions, and provide job security to employees. They expect US managers to consult subordinates, to delegate tasks to subordinates, and to prefer team's work because they believe that better decisions are made by groups rather than by individual.

In a sharp contrast to their own autocratic, forceful management philosophy, South African managers believe that an ideal US manager in IJVs should be people-oriented. They expect the JV's managers to establish career path for employees and managers giving some certainty to their prospect, and guiding them in how to improve their positions in the IJV. They also expect working conditions to improve and discrimination in the workplace to be eliminated.

These findings replicate previous international studies which found that managers in 14 countries expected their employees to take initiative while at the same time the same managers did not believe that their subordinates had the potential for such initiative (Haire, Ghiselli \& Porter, 1966).

South African managers attitudes toward the foreign manager of the IJV provide some support to the House et al.'s (2004) finding for in-group collectivist rather than an 
individualistic South African society. Also, these findings support the shared value of humaneness (Ubuntu) - a pervasive spirit of caring and community, harmony and hospitality, respect and responsiveness that individuals and groups display for one another (Mangaliso, 2001).

Clearly, South African managers portray the ideal US managers for IJVs quite differently from their own personal management philosophy. There are three possible interpretations of the result. First, the shift may indicate that South African managers are aware of the fact that IJVs differ from other enterprises. Since IJVs are shared entities, an ideal IJV manager should be diplomatic and sophisticated. Coordination, communication and liaison probably are more important than strict control and forceful execution. US managers are known to be strong in democratic, participate, and people-oriented management. Accordingly, it seems that South African managers highly regard those strengths of US managers that comply with the characters of JIVs.

Second, one may also argue that South African managers simply do not like to be managed by others in a taskoriented, less friendly way. Thus South African managers prefer their US bosses and colleagues to be sympathetic in their management of the IJVs.

Third, it is possible that these conflicting results reflect the composition of the sample where over 60 percent of the respondents were women. Women in all cultures tend to be more feminine (Hofstede, 1980) in their management approach. South African women who took part in this survey may have different expectations than South African male managers who were surveyed in previous studies. The implications of these findings are discussed next.

\section{Conclusions}

The finding has valuable implications for prospective US firms. First, US partners should realize that South African managers are realistic about IJV's singularity, and do not expect US managers to behave similarly to them. This lays the groundwork for better understanding and accommodation. Second, US partners should appreciate the fact that, although the managerial approach and expertise of South African and US managers are quite different, the two basically complement each other. Because the need for highest work performance and strict control is high in IJVs, US partners should be keen to bring South African managerial talents to the venture.

The results indicate that South African managers stated clearly that they were concerned with basic employment issues rather than with HR management methods. They did not expect US managers to transfer Western style HR methods to South Africa but rather to implement a just and considerate management system. In such a system employees would clearly understand what are they supposed to do to get promoted, the working environment would be hospitable, and workers would not be discriminated against because if their color, ethnic background or nationality.
Awareness of HQs' officials and expatriate managers of South African value system and of potential cultural differences, and pre-departure training are partial solutions to differences in expectations between South African and US partners. Ownership structure and product market focus are crucial, however, these may hinge on their ability to manage challenges (Tong, Reuer \& Peng, 2008). Rather than waiting for cultural differences unexpectedly immerge while the joint venture is already operational those cultural differences should be recognized during the decision making process of the creation of the joint ventures. Both parent companies should spell out their cultural expectations to create trust and good working conditions between the partners.

Future studies may contribute finer grained understanding of other forms of international direct investment applying real options theory and exploring ways of grouping countries and geopolitical locations in terms of cultures and institutions.

\section{References}

Abratt, R. \& Da Silva, L.H. 2002. 'Potential of the Internet as a retailing channel in South Africa', Journal of African Business, 3:(3) 69-90.

Adner, R. \& Levinthal, D. 2004. 'What is not a real option: Considering boundaries for the application of real options to business strategy', Academy of Management Review, 29: 7485.

Akande, A. 1991a. 'Human resources strategy: Focusing on Joseph’s analytic work’, Management Decision, 21:51-66.

Akande, A. 1991b. 'How managers express their creativity', International Journal of Manpower, 12:17-19.

Akande, A. 1992a. 'Applying Deming to service', Management Decision, 30:3-18.

Akande, A. 1992b. 'Sexual harassment: An employment issue’, Equal Opportunities International, 11: 8-12.

Akande, A. 1994. 'The glass ceiling: Women and mentoring in management and business,' Employee Counselling Today, 6:21-26

Akande, A. \& Odewale, F. 1994. 'One more time: How to stop company rumours', Leadership \& Organization Development Journal, 15:27-40.

Arnolds, C. \& Boshoff, C. 2003. 'The influence of McLelland's need satisfaction theory on employee job performance: A causal study', Journal of African Business, 4(3): 55-81.

Arnolds, C. \& Boshoff, C. 2002. 'The interactive relationship of employee commitment types', Journal of African Business, 3:(1) 7-29.

Awadzi, W. K. 1987. 'Determinants of joint venture performance: A study of international joint ventures in the 
United States'. Ph.D. dissertation, Louisiana State University.

Badenhorst, J.A. 1994. 'Unethical behavior in procurement: A perspective on causes and solutions', Journal of Business Ethics, 13(9):739-746.

Baird, I. S., Lyle, M.A. \& Wharton, R. 1990. 'Attitudinal differences between American and Chinese managers regarding joint ventures management', Management International Review, 30 [Special issue]:53-68.

Banai, M. \& Teng, B.S. 1996. 'Comparing job characteristics, leadership style, and alienation in Russian public and private enterprises', Journal of International Management, 2(3):201-224.

Banai, M., Chanin, M. \& Teng, B.S. 1999. 'Russian managers' perceptions of prospective Russian - US joint ventures', International Business Review, 8:17-37.

Beamish, P. W. 1984. 'Joint venture performance in developing countries'. Ph.D. dissertation, University of Western Ontario.

Beamish, P. W. 1988. Multinational joint ventures in developing countries. London: Rutledge.

Beamish, P. W. 1993. 'The characteristics of joint ventures in the People's Republic of China', Journal of International Marketing, 1(2):29-48.

Beamish, P. W. \& Inkpen, A. C. 1995. 'Keeping international joint ventures stable and profitable', Long Range Planning, 28(3):26-36.

Berdrow, I. \& Lane, H.W. 2003. 'International joint ventures: Creating value through successful knowledge management', Journal of World Business, 38:15-30.

Blodgett, L.L. 1991. 'Partners contribution as predictors of equity share in international joint ventures', Journal of International Business Studies, 22(1):63-78.

Boateng, A. \& Glaister, K. W. 2002. 'Performance of international joint ventures: Evidence for West Africa', International Business Review, 11(5):523-541.

Boersma, M. F., Buckley, P.J. \& Ghauri, P.N. 2003. 'Trust in international joint venture relationships', Journal of Business Research, 56:1031-1042.

www.businessmap.co.za Information on foreign investment in South Africa.

Cattaneo, E. 1992. 'Managing joint ventures in Russia: Can the problems be solved?’, Long Range Planning, 25(5):6872 .

Chalos, P. \& O'Connor, N.G. 2004. 'Determinants of the use of various control mechanisms in US-Chinese joint ventures', Accounting, Organizations and Society, 29:591608.
Chi, T. 2000. 'Option to acquire or divest a joint venture', Strategic Management Journal, 21: 665-685.

Child, J. \& Yan, Y. 2003. 'Predicting the performance of international joint ventures: An investigation in China', Journal of Management Studies, 40(2):283-320.

Das, T. K. \& Teng, B.S. 2000. 'Instabilities of strategic alliances: An internal tensions perspective', Organization Science, 11(1):77-101.

Delios, A. \& Henisz, W.J. 2000. 'Japanese firms' investment strategies in emerging economies’, Academy of Management Journal, 43:305-313.

Desai, M.A., Foley, C.F. \& Hines, J. R. 2004. 'The costs of shared ownership: Evidence from international joint ventures', Journal of Financial Economics, 73:323-374.

Dyer, J.H., Kale, P. \& Singh, H. 2004. 'When to ally and when to acquire', Harvard Business Review, 82:108-115.

Engelbrecht, A. \& Fischer, H. 1995. 'The managerial performance implications of a developmental assessment center', Human Relations, 48(4):387-405.

Fey, C. 1995. 'Important design characteristics for Russian joint ventures success: A time series study', European Management journal, 13:405-415.

Fey, C. \& Beamish, P. 2001. 'Organizational climate similarity and performance: International joint ventures in Russia’, Organization Studies, 22:853-882.

Folta, T.B. \& Miller, K.D. 2002. 'Real options and equity partnerships’, Strategic Management Journal, 23:77-88.

Geringer, J.M. \& Hebert, L. 1989. 'Control and performance in international joint ventures', Journal of International Business studies, 20(2):235-254.

Ghosh, S. 2001. 'Ethnic diversity and managerial effectiveness in South Africa', The Academy of Management Executive, 15(3):136-138.

Gomes-Casseres, B. 1987. 'Joint ventures instability: Is it a problem?’, Columbia Journal of World Business, 22(2):97102.

Guillen, M. F. 2002. 'Structural inertia, imitation, and foreign expansion: South Korean firms and business groups in China, 1987-95', Academy of Management Journal, 45:509-525.

Haire, M., Ghiselli, E.E. \& Porter, L.W. 1966. Managerial thinking: An international study. New York: John Wiley.

Hajisimitriou, Y.A. \& Georgiou, A.C. 2002. 'A goal programming model for partner selection decisions in international joint ventures', European Journal of Operational Research, 138:649-662. 
Harrigan, K.R. 1985. Strategies for joint ventures. Lexington, MA: Lexington Books.

Hebert, L. 1996. 'Does control matter? A path model of the control-performance relationship in international joint ventures', Management International Review, 1(1):27-39.

Hennart, J. F. 1988. 'A transaction costs theory of equity joint ventures’, Strategic Management Journal, 9:361-374.

Hennart, J. F. \& Zeng, M. 2002. 'Cross-cultural differences and joint venture longevity', Journal of International Business Studies, 33:699-716.

Hofmeyr, K., Templer, A. \& Beaty, D. 1994. 'South Africa: Researching contrasts and contradictions in a context of change', International Studies of Management and Organization, 24(1-2):190-208.

Hofstede, G. 1980. Culture's consequences: International differences in work related values. Beverly Hills, CA: Sage Publications.

Hofstede, G. 1997. Cultures and organizations: Software of the mind. New York: McGraw-Hill.

Holtzhausen, D. 2002. 'The effects of divisionalised and centralized organisational structure on a formal internal communication function in a South African organisation', Journal of Communication Management, 6(4):323-350.

Hough, W.J. 1990. 'New incentives lure western investment', Management Review, March:38-41.

House, R.J., Hanges, P.J., Mansour J., Dorfman, P. \& Gupta, V. (Eds.). 2004. Culture, leadership, and organizations: The GLOBE study of 62 societies. Thousand Oaks, CA: Sage.

Inkpen, A.C. \& Beamish, P.W. 1997. 'Knowledge, bargaining power, and the instability of international joint ventures', Academy of Management Review, 22(1):177-202.

Ireland, R.D., Hitt, M.A. \& Vaidyanath, D. 2002. 'Alliance management as a source of competitive advantages', Journal of Management, 28:413-440.

Jackson, T., Hill S., Tamangani, Z. \& Chipandambira, F. 2000. 'The management of people and organization in South Africa and Zimbabwe: A cross-cultural study', Management Research News, 23(2-4):98-100.

Killing, J. P. 1982. 'How to make a global joint venture work', Harvard Business Review, May/June:120-127.

Killing, J. P. 1983. Strategies for joint venture success. London: Croom Helm.

Kogut, B. 1988a. 'A study of the life cycle of joint venture'. In Contractor, F.J. \& Lorange, P. (Eds.). Cooperative strategies in international business. Lexington, MA: Lexington Books, 169-185.
Kogut, B. 1988b. 'Joint ventures: Theoretical and empirical perspectives’, Strategic Management Journal, 9:319-332.

Kogut, B. 1989. 'The stability of joint ventures: Reciprocity and competitive rivalry', Journal of Industrial Economics. 38(2):183-198.

Kropp F. \& Lindsay, N. 2001. 'South African business dynamics: Measuring entrepreneurship', Journal of African Business, 2:(1):23-45.

Lane, H.W. \& Beamish, P.W. 1990. 'Cross cultural cooperative behavior in LDCs,' Management International Review, 30 [Special issue]:87-102.

Lawrence, P. \& Vlachoutsicos, C. 1993. 'Joint entures in Russia: Put the locals in charge', Harvard Business Review, 71(1):44-54.

Lin, J. L., Yu, C. M. J. \& Seetoo, D.H. W. 1997. 'Motivations, partners' contributions, and control of international joint ventures'. In Beamish, P. W. \& Killing, J. P. (Eds.). Cooperative strategies: Asian Pacific perspectives. San Francisco, CA: New Lexington Press, pp. 115-134.

Madhok, A. 2006. 'Revisiting multinational firms' tolerance for joint ventures: a trust-based approach', Journal of International Business Studies, 37:30-43.

Mangaliso, M.P. 2001. 'Building competitive advantage from Ubuntu: Management lessons from South Africa', Academy of Management Executive, 15(3):23-35.

Mangaliso, M.P. \& Nkomo, S.M. 2001a. 'Eskom's chairman Reuel Khoza on the transformation of South African business', The Academy of Management Executive, 15(3):8-15.

Mangaliso, M.P. \& Nkomo, S.M. 2001b. 'HerdBoys McCann- Erickson's chairman Peter Vundla on black entrepreneurs and economic empowerment', The Academy of Management Executive, 15(3):16-22

Mjoen, H. \& Tallman, S. 1997. 'Control and performance in international joint ventures’, Organization Science, 8(3):257-274.

Newman, W. H. 1992. 'Focused joint ventures' in transforming economies’, Academy of Management Executive, 6(1):67-75.

Pantzalis, C. 2002. 'Does location matter? An empirical analysis of geographic scope and MNC market valuation', Journal of International Business Studies, 32:133-152.

Park, S. H. \& Ungson, G. R. 1997. 'The effect of national culture, organizational complementarity and economic motivation on joint venture dissolution', Academy of Management Journal, 40(2):279-307.

US Embassy. 2009. United States foreign diversified investments. [Online] URl: http://pretoria.usembassy.gov 
Prahalad, C.K. \& Lieberthal, K. 2003. 'The end of corporate imperialism', Harvard Business Review, 61:109-117.

Radder, P.E. 2000. 'The South African clothing retailer and environmental change: A suggested contemporary approach', Journal of African Business, 1:(2) 75-89.

Reich, R. B. \& Mankin, E.D. 1986. 'Joint ventures with Japan give away our future', Harvard Business Review, 64(2):78-86.

Ring, P. S. \& Van de Ven, A. H. 1992. 'Structuring cooperative relationships between organizations', Strategic Management Journal, 13:483-498.

Rosenkopf, L. \& Almeida, P. 2003. 'Overcoming local search athrough alliances and mobility', Management Science, 49:751-766.

Shenkar, O. \& Yan, A. 2002. 'Failure as a consequence of partner politics: Learning from the life and death of an international cooperative venture', Human Relations, 55:565-601.

Shenkar, O. \& Zeira, Y. 1987. 'Human resource management in international joint ventures: Directions for research', Academy of Management Review, 12(3):546-557.

Sudeshna G. 2001. 'Ethnic diversity and managerial effectiveness in South Africa', The Academy of Management Executive, 15(3):136-137.

Tait, M. \& Tait, M. 2000. 'The influence of selected factors on the perceptions of managers of small business firms regarding legal firm: A South African perspective', Journal of African Business, 1:3.

Tallman, S., Sutcliffe, A.G. \& Antonian, B.A. 1997. 'Strategic and organizational issues in international joint ventures in Moscow'. In Beamish, P.W. \& Killing, J.P. (Eds.). Cooperative strategies. Vol. 2, European Perspectives. San Francisco, CA: Lexington Press, pp. 184211.

Tang, L.T.P., et al. 2006. 'The love of money and pay satisfaction: An examination of measurement equivalence and functional equivalence in 27 samples around the world', Management and Organizational Review, 2:423-452.

Tong, T.W. \& Reuer, J.I. 2006. 'Firm and industry influences on the value of growth options', Strategic Organization, 4:71-95.

Tong, T.W., Reuer, J.I., Peng, M. W. 2008. 'International joint ventures and the value of growth options', Academic of Management Journal, 51 : 1014-1024.

Triandis, H.C. 1995. Individualism and collectivism. Boulder, CO: Westview Press.

Triandis, H.C. \& Gelfand, M.J. 1998. 'Converging measurement of horizontal and vertical individualism and collectivism', Journal of Personality and Social Psychology, 74(1): 118-128.

Van Eeden, S., Viviers, S. \& \& Venter, D. 2003. 'An exploratory study of selected problems encountered by small businesses in a South African context', Journal of African Business, 5:(1) 45-72.

Wallroth, C. 1998. 'Personnel administration and personnel development'. In Wohlgemuth L., Carlsson J. \& Kifle, H. (Eds.). Institution building and leadership in Africa. Stockholm: Nordiska Afrikainstitutet.

Wright, M., Filatotchev, I., Hoskisson, R. \& Peng, M.W. 2005. 'Strategy research in emerging economies: Challenging the conventional wisdom', Journal of Management Studies, 42: 1-33.

Yan, Y. 2003. 'A comparative study of human resource management practices in international joint ventures: The impact of national origin', Int J. of Human Resource Management, 14: 487-510.

Yan, A. \& Gray, B. 1994. 'Bargaining power, management control, and performance in United States - China jointventures: A comparative case study', Academy of Management Journal, 37(6):1478-1517.

Zaheer, S., Schomaker, M. \& Genc, M. 2003. 'Identity versus culture in mergers of equals', European Management Journal, 21:185-191. 
